\title{
Upaya Peningkatan Hasil Belajar Tematik Melalui Pendekatan Problem Based Learning Siswa Kelas 5 SD
}

\author{
Dimas Anjar Kisworo ${ }^{1 *}$, Naniek Sulistya Wardani ${ }^{2}$ \\ 1,2 PPG Prajabatan - Guru Kelas SD Universitas Kristen Satya Wacana, Salatiga, Indonesia
}

\section{ART I CLE I N F O}

Article history:

Received April 14, 2021

Revised May 25, 2021

Accepted June 20, 2021

Available online August 25, 2021

Kata Kunci:

Problem Based Learning, Hasil Belajar, Pembelajaran Tematik

Keywords:

Problem Based Learning, Learning Outcomes, Thematic Learning

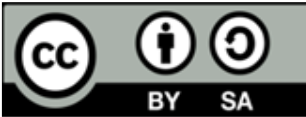

This is an open access article under the CC BY-SA license.

Copyright $(\subseteq 2021$ by Author. Published by Universitas Pendidikan Ganesha.

\begin{abstract}
A B S T R A K
Pembelajaran tematik merupakan kegiatan pembelajaran yang dirancang untuk memaksimalkan peran siswa dalam proses belajar, hanya saja dalam pengimplemtasiannya proses pembelajaran tematik cenderung berfokus pada guru, yang berakibat pada rendahnya hasil belajar siswa. Tujuan dari penelitian ini yakni untuk mengetahui apakah peningkatan hasil belajar tematik siswa kelas 5 SD dapat diupayakan melalui pendekatan Problem Based Learning. Penelitian ini menggunakan model Penelitian Tindakan Kelas (PTK) yang terdiri dari 3 tahap yakni, perencanaan tindakan, pelaksanaan tindakan dan observasi, refleksi. Subjek penelitian yaitu 32 siswa kelas 5 SD. Pengumpulan data dilakukan dengan menggunakan teknik tes dan teknik nontes. Instrumen yang digunakan adalah butir soal dan lembar observasi. Teknik analisis data menggunakan uji t-test. Hasil penelitian ditunjukkan perbedaan ratarata hasil belajar prasiklus sebesar 76,46 dengan persentase ketuntasan $59,38 \%$ dan siklus 1 sebesar 85,03 dengan persentase ketuntasan $68,75 \%$ dan terus meningkat rata-rata pada siklus 2 sebesar 87,49 dengan persentase ketuntasan $87,50 \%$. Di samping itu, uji t sebesar 5,328 artinya terdapat perbedaan selisih rata-rata antara prasiklus dan siklus 1 sebesar 8,57 . Signifikansi $5 \%$ sebesar 0,000 yang berarti perbedaan rata-rata hasil belajar bermakna. Uji t prasiklus dengan siklus 2 dengan hasil 5,328 semakin meningkat pada rata-rata hasil belajar sebesar 11,03 dengan nilai signifikansi $5 \%$ adalah 0,000 yang berarti perbedaan rata-rata hasil belajar bermakna. Sehingga dapat disimpulkan bahwa pendekatan Problem Based Learning dapat meningkatkan hasil belajar tematik siswa kelas 5 Sekolah Dasar.
\end{abstract}

\section{A B S T R A C T}

Thematic learning is a learning activity designed to maximize the role of students in the learning process, only in its implementation, the thematic learning process tends to focus on the teacher, which results in low student learning outcomes. This study aims to find out whether the improvement of thematic learning outcomes of 5th-grade elementary school students can be pursued through a Problem Based Learning approach. This study uses a Classroom Action Research (CAR) model which consists of 3 stages, namely, action planning, action implementation and observation, reflection. The research subjects were 32 5th grade elementary school students. Data collection is done by using test techniques and non-test techniques. The instruments used are questions and observation sheets. The data analysis technique used the t-test. The results showed that the average difference in pre-cycle learning outcomes was 76.46 with a percentage of completeness $59.38 \%$ and cycle 1 of 85.03 with a percentage of completeness of $68.75 \%$ and continued to increase on average in cycle 2 of 87.49 with percentage completeness of $87.50 \%$. In addition, the t-test of 5.328 means that there is a difference in the average difference between pre-cycle and cycle 1 of 8.57 . The significance of $5 \%$ is 0.000 , which means the difference in the average learning outcomes is significant. Pre-cycle $t$-test with cycle 2 with the results of 5.328 increased in the average learning outcomes of 11.03 with a significance value of $5 \%$ is 0.000 which means the difference in the average learning outcomes is significant. So it can be concluded that the Problem Based Learning approach can improve thematic learning outcomes of 5thgrade elementary school students. 


\section{PENDAHULUAN}

Pembelajaran berbasis tematik adalah model pembelajaran yang mengintegrasikan atau menggabungkan beberapa muatan pelajaran dalam satu proses pembelajaran yang memungkinkan siswa secara individu maupun kelompok aktif secara fisik dalam menggali dan menentukan konsep serta prinsip-prinsip keilmuan secara bermakna dan autentik (Rusman, 2017; Titik et al., 2017). Muatan pelajaran yang terdapat pada pembelajaran tematik adalah muatan PPKn, Bahasa Indonesia, Ilmu Pengetahuan Alam (IPA), Ilmu Pengetahuan Sosial (IPS), Seni Budaya dan Prakarya, Matematika serta Jasmani, Olahraga dan Kesehatan (Sari et al., 2018; Yanthi et al., 2020). Pada proses pembelajaran tematik, guru berfokus dalam melatih siswa untuk berpikir kritis, mengembangkan kreativitas, mengembangkan kemampuan memecahkan masalah dan mengembangkan kemampuan dalam menyampaikan informasi (Wahyuni et al., 2016). Sehingga untuk memaksimalkan tujuan pembelajaran tersebut proses pembelajaran tematik diupayakan untuk berpusat kepada siswa atau student centered.

Namun pada kenyataannya masalah utama dari pembelajaran tematik yakni proses pembelajaran yang masih berpusat pada guru yaitu guru selalu menyampaikan materi dengan ceramah dan memberikan kesempatan untuk siswa tanya jawab (Ananda \& Fadhilaturrahmi, 2018; Muhith, 2018). Proses pembelajaran tanpa memberikan siswa untuk berdiskusi dengan kelompok dan tidak menekankan pada pemahaman konsep. Hal ini sejalan dengan kondisi di lapangan dari hasil praktikum mengajar secara konvensional di kelas 5C SD Negeri Gendongan 01 Salatiga, menyatakan bahwa hasil belajar siswa masih di bawah KKM $\geq 85$, yaitu skor rata-rata sebesar 76,46. Secara individual dari 32 siswa, 13 siswa (41\% dari seluruh siswa) memperoleh skor di atas KKM, dan 19 siswa (59\% dari seluruh siswa) mendapatkan skor di bawah KKM. Sebanyak 41\% dari seluruh siswa tidak mencapai ketuntasan. Di samping itu, skor dari Penilaian Tengah Semester (PTS) masih di bawah standar KKM yang ditetapkan. Dari 32 siswa kelas 5 terdapat 18 siswa atau 56\% dari seluruh siswa mendapatkan skor di atas KKM dan 14 siswa atau $44 \%$ dari seluruh siswa belum memenuhi KKM atau belum tuntas. Pembelajaran yang dilakukan guru kelas dengan memberikan materi melalui penjelasan yang sesuai dengan yang ada di buku dan proses pembelajaran yang dilakukan adalah konvensional. Artinya pembelajaran dilakukan dengan pembelajaran yang sama dan terus menerus. Selama proses pembelajaran siswa tidak memiliki semangat saat mengikuti pembelajaran dan jarang memberikan pendapat atau mengajukan pertanyaan dan tidak terjadi diskusi antara guru dan siswa, sehingga berakibat pada rendahnyan hasil belajar siswa pada pembelajaran tematik.

Salah satu upaya yang dapat dilakukan untuk meningkatkan hasil belajar siswa dalam proses pembelajaran tematik yakni memilih pendekatan yang sesuai dengan kebutuhan siswa untuk meningkatkan aspek kognitif, afektif dan psikomotoriknya. Penggunaan pendekatan pembelajaran yang tepat akan dapat meningkatkan fokus belajar siswa sehingga materi yang sedang diberikan dapat diterima dengan baik (Ainin, 2017). Salah satu pendekatan yang tepat digunakan untuk meningkatkan hasil belajar siswa dalam pembelajaran tematik yakni pendekatan problem based learning. Pendekatan ini memfokuskan siswa untuk berpikir kritis dan kreatif dalam memecahkan masalah yang diberikan oleh guru (Gultom \& Adam, 2018). Keterlibatan langsung dalam proses pembelajaran memberikan pengalaman langsung kepada siswa sehingga pembelajaran yang didapatkan sangat bermakna.

Secara lebih rinci Problem based learning (PBL) diartikan sebagai suatu pendekatan pembelajaran yang menggunakan masalah dunia nyata sebagai suatu konteks bagi peserta didik untuk belajar tentang cara berpikir kritis dan keterampilan pemecahan masalah, serta untuk memperoleh pengetahuan dan konsep yang esensial dari materi pelajaran (Aji et al., 2019; Chanifah et al., 2019; Pamungkas et al., 2018). Dalam proses pembelajaran PBL peserta didik disuguhkan berbagai situasi permasalahan yang autentik dan bermakna sehingga dapat digunakan sebagai batu loncatan untuk investigasi dan penyelidikan (Setiowati, 2019). Pembelajaran dengan menggunakan pendekatan PBL dimulai dengan dengan memberikan masalah nyata kepada siswa yang bekerjasama dengan kelompok untuk menemukan dan menyelesaikan masalah dan menemukan pengetahuan yang baru secara langsung (Purnaningsih et al., 2019). Pemecahan masalah melibatkan berbagai sumber belajar yang nantinya diakhiri dengan evaluasi dari informasi yang sudah didapat dari berbagai sumber belajar agar diperoleh solusi pemecahan masalah yang paling tepat (Triwibowo et al., 2020).

Selain dapat meningkatkan hasil belajar siswa pendekatan problem based learning juga dapat menjadikan siswa aktif belajar, berani dan mandiri dalam menyelesaikan masalah yang berkaitan dengan kehidupan sehari-hari siswa (Syafriana, 2017). Hal ini didukung oleh hasil penelitian (Silaban et al., 2020) yang menunjukkan bahwa pendekatan problem based learning secara signifikan mampu meningkatkan hasil belajar siswa, dibandingkan dengan menggunakan model konvensional. Penelitian ini juga relevan dengan penelitian tindakan kelas yang dilakukan oleh (Eismawati et al., 2019) mengenai penggunaan pendekatan PBL dalam pembelajaran matematika dan menunjukkan hasil bahwa pend ekatan PBL mampu secara signifikan mampu meningkatkan hasil belajar siswa kelas IV sekolah dasar. Berdasarkan hasil 
penelitian tersebut dapat disimpulkan bahwa penggunaan pendekatan PBL dalam proses pembelajaran secara signifikan dapat meningkatkan hasil belajar siswa. Penelitian ini difokuskan terhadap upaya peningkatan hasil belajar tematik melalui pendekatan problem based learning siswa kelas 5 SD yang belum pernah dilaksanakan sebelumnya, dengan tujuan untuk mengetahui apakah peningkatan hasil belajar tematik siswa kelas 5 SD dapat diupayakan melalui pendekatan Problem Based Learning.

\section{METODE}

Penelitian ini merupakan penelitian tindakan kelas yang dilakukan di SD Negeri Gendongan 01 Salatiga Kecamatan Tingkir Kota Salatiga pada semester II tahun pelajaran 2020/2021. Penelitian ini dilakukan di kelas 5C dengan jumlah siswa 32 siswa yang terdiri 16 siswa laki-laki dan 16 siswa perempuan. Pelaksanaan penelitian dilakukan dalam 3 tahap siklus yang terdiri dari tahap prasiklus, siklus I dan siklus II. Pada tahap prasiklus dilakukan proses pengamatan dan observasi terhadap hasil belajar siswa sebelum diberikan perlakuan. Selanjutnya pada siklus I dan II dilaksanakan tahap persiapan, implementasi, observasi, dan evaluasi terhadap proses pembelajarannya. Teknik pengumpulan data dalam penelitian tindakan kelas ini menggunakan teknik tes untuk penilaian kognitif dan teknik nontes (observasi) untuk penilaian afektif dan psikomotor. Instrumen penelitian yang digunakan adalah butir soal dan lembar observasi. Teknik tes diberikan di akhir pembelajaran setelah proses pembelajaran selesai dilaksanakan dan teknik nontes dilakukan selama proses pembelajaran dari awal hingga akhir. Teknik analisis data menggunakan uji t dengan Independent Sample T-Test.

Uji validitas instrumen tes hasil belajar dikatakan valid apabila koefisien korelasi $\geq 0,20$ (Wardani, 2012). Analisis data dilakukan dengan bantuan SPSS 22. Instrumen butir soal siklus 1 terdiri dari 12 pernyataan, hasilnya dinyatakan valid dengan $0,354<r>0,551$. Instrumen diuji cobakan pada 30 siswa. Instrumen butir soal siklus 2 terdiri dari 12 pernyataan, hasilnya dinyatakan valid dengan $0,223<r>$ 0,588 . Adapun kriteria indeks validitas soal dibedakan menjadi lima kategori, yaitu sangat tinggi, tinggi, cukup, rendah dan sangat rendah (Wardani, 2012:344). Secara rinci kriteria indeks validitas disajikan melalui Tabel 1.

Tabel 1. Kriteria Indeks Reliabilitas

\begin{tabular}{ccl}
\hline No & Indeks & Kriteria \\
\hline 1 & $0,81-1,00$ & Sangat Tinggi \\
2 & $0,61-0,80$ & Tinggi \\
3 & $0,41-0,60$ & Cukup \\
4 & $0,21-0,40$ & Rendah \\
5 & $0,00-0,20$ & Sangat Rendah \\
\hline
\end{tabular}

Teknik analisis data dilakukan dengan menggunakan uji t dengan Independent Sample T-Test. Uji statistik inferensial dilakukan jika memenuhi uji prasyarat parametrik yaitu: a) uji normalitas, b) uji homogenitas. Uji statistik inferensial yang digunakan adalah uji beda atau uji $t$-test (Independent Sample TTest) yang berfungsi untuk membandingkan rerata hasil belajar prasiklus dengan siklus 1 dan siklus 2 . Uji normalitas data dilakukan dengan bantuan uji SPSS 22 Kolmogorov-Smirnov, dengan dasar pengambilan keputusan yaitu jika nilai signifikansi $>0,05$, maka data berdistribusi normal. Uji prasyarat selanjutnya adalah uji homogenitas untuk mengetahui apakah data pada kelas 5C SD Negeri Gendongan 01 Salatiga memiliki varian yang sama atau homogen.

\section{HASIL DAN PEMBAHASAN}

Hasil

Hasil observasi pada tahap prasiklus menunjukkan bahwa skor hasil belajar tematik berdasarkan ketuntasan siswa kelas 5 SD yang diperoleh sebelum diberikan tindakan atau prasiklus yang kemudian dianalisis secara deskriptif disajikan melalui Tabel 2.

Tabel 2. Distribusi Hasil Belajar Tematik Berdasarkan Ketuntasan Prasiklus

\begin{tabular}{ccccc}
\hline Skor & Jumlah Siswa & Persentase (\%) & Pencapaian KKM & Predikat \\
\hline $89-96$ & 4 & 12,50 & Tuntas & Sangat Baik \\
$85-88$ & 9 & 28.13 & Tuntas & Baik \\
$71-79$ & 6 & 18,75 & Tidak Tuntas & Cukup \\
\hline
\end{tabular}




\begin{tabular}{lcccc}
\hline \multicolumn{1}{c}{ Skor } & Jumlah Siswa & Persentase (\%) & Pencapaian KKM & Predikat \\
\hline $65-70$ & 10 & 31,25 & Tidak Tuntas & Rendah \\
$57-64$ & 3 & 9,38 & Tidak Tuntas & Sangat Rendah \\
\hline Jumlah & $\mathbf{3 2}$ & $\mathbf{1 0 0}$ & & \\
\hline
\end{tabular}

Pada Tabel 2 diketahui bahwa pada pembelajaran tematik prasiklus, dari 32 siswa kelas 5 SD yang mendapatkan skor di atas KKM yaitu 13 siswa (40,63\% dari 32 siswa), dan yang mendapatkan nilai di bawah KKM yaitu 19 siswa (59,38\% dari 32 siswa). Skor rata-rata pada prasiklus sebesar 76,46. Secara terperinci, hasil belajar tematik berdasarkan ketuntasan subtema peristiwa masa penjajahan disajikan melalui gambar 2 di bawah ini. Berdasarkan hasil belajar tematik pada ketuntasan prasiklus yang pembelajarannya dilakukan secara konvensional menunjukkan $59 \%$ dari seluruh siswa atau separuh lebih siswa yang belum tuntas dalam hasil belajar tematik. Oleh karena itu, perlu diberikan tindakan melalui pendekatan PBL agar banyak siswa yang tuntas dan mengalami peningkatan hasil belajar tematik. Tahap siklus pertama diberikan tindakan berupa pembelajaran PBL. Pembelajaran siklus 1 dilakukan melalui pengamatan oleh observer. Observer mengamati proses pembelajaran dari awal hingga akhir pembelajaran. Adapun hasil belajar yang ditunjukkan pada pelaksanaan siklus I dapat dilihat pada tabel 3 berikut.

Tabel 3. Distribusi Hasil Belajar Tematik Berdasarkan Ketuntasan Siklus 1

\begin{tabular}{lcccc}
\hline \multicolumn{1}{c}{ Skor } & Jumlah Siswa & Persentase (\%) & Pencapaian KKM & Predikat \\
\hline $90-96$ & 7 & 21,88 & Tuntas & Sangat Baik \\
$85-89$ & 15 & 46,88 & Tuntas & Baik \\
$73-84$ & 7 & 21,88 & Tidak Tuntas & Cukup \\
$61-72$ & 3 & 9,38 & Tidak Tuntas & Rendah \\
\hline Jumlah & $\mathbf{3 2}$ & $\mathbf{1 0 0}$ & & \\
\hline
\end{tabular}

Tabel 3 menunjukkan bahwa pembelajaran tematik siklus 1, dari 32 siswa kelas 5 SD yang mendapatkan skor di atas KKM yaitu 22 siswa (68,75\% dari 32 siswa) sedangkan yang mendapatkan skor di bawah KKM yaitu 10 siswa (31,25\% dari 32 siswa). Nilai rata-rata pada siklus 1 yaitu 85.03 Dari siklus 1 ini menunjukkan adanya kenaikan jumlah ketuntasan siswa naik sebesar 9 siswa $(28,13 \%$ dari 32 siswa). Secara terperinci, hasil belajar tematik berdasarkan ketuntasan Subtema 2 Peristiwa Kebangsaan Seputar Proklamasi dapat dilihat pada diagarm lingkaran di bawah ini.

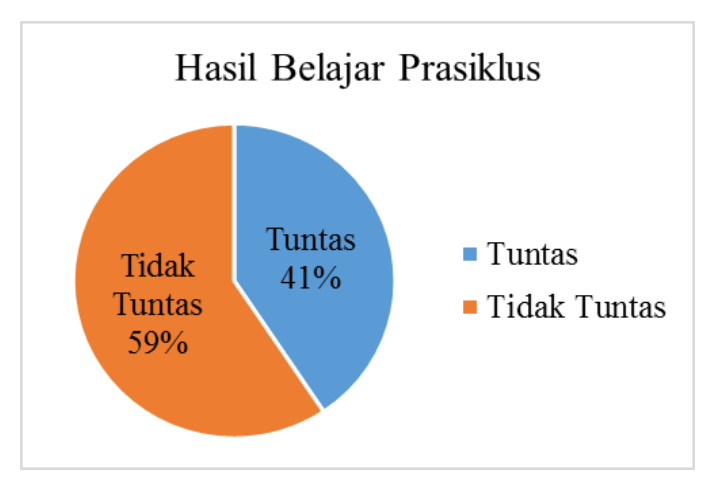

Gambar 1. Diagram Lingkaran Hasil Belajar Tematik Berdasarkan Ketuntasan Prasiklus

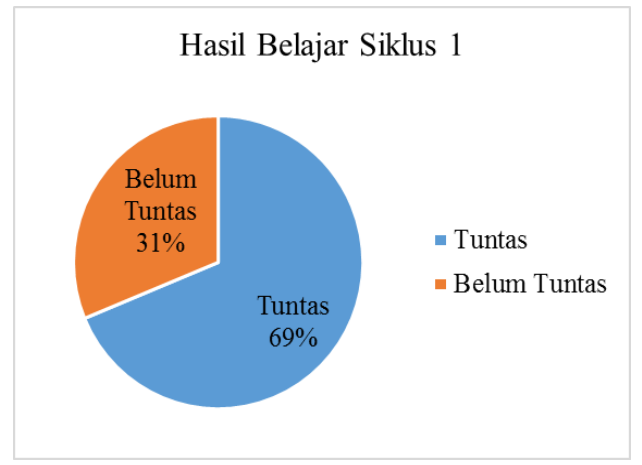

Gambar 2. Diagram Lingkaran Hasil Belajar Tematik Berdasarkan Ketuntasan Siklus 1

Pada gambar 2 nampak bahwa pada saat dilakukan tindakan jumlah siswa yang tuntas ada 22 siswa (68,75\% dari 32 siswa) belum mencapai 85\% dari jumlah keseluruhan kelas. Hal ini sejalan dengan hasil proses observasi, dimana terdapat beberapa kelemahan dan kelebihan selama pelaksanaan pembelajaran siklus I. Adapun kelemahan yang diperoleh adalah kebingungan siswa dalam melakukan diskusi secara daring pada grup yang terpisah, tidak seperti di kelas tatap muka langsung di mana siswa langsung bisa bergerak menuju kelompok akan tetapi dalam Zoom ini siswa mengikuti petunjuk yang belum pernah dilakukan saat melakukan diskusi secara daring. Kelebihan yang diperoleh adalah kegiatan berdiskusi bisa berjalan dengan lancar dan siswa dapat mempresentasikan hasil temuan informasi dan pemecahan dengan tepat sehingga hasil diskusi sesuai dengan harapan guru. Untuk lebih meningkatkan hasil belajar tematik siswa, maka diperlukan tindakan yang kedua agar ketuntasan yang diharapkan 
menjadi 85\%. Tindakan yang dilakukan yakni dengan melaksanakan siklus II dengan hasil yang diperoleh disajikan pada Tabel 4.

Tabel 4. Distribusi Hasil Belajar Tematik Berdasarkan Ketuntasan Siklus 2

\begin{tabular}{lccll}
\hline \multicolumn{1}{c}{ Skor } & Jumlah Siswa & Persentase (\%) & \multicolumn{1}{c}{ Pencapaian KKM } & \multicolumn{1}{c}{ Predikat } \\
\hline $90-98$ & 11 & 34,38 & Tuntas & Sangat Baik \\
$85-89$ & 17 & 53,13 & Tuntas & Baik \\
$68-84$ & 4 & 12,50 & Tidak Tuntas & Cukup \\
\hline Jumlah & $\mathbf{3 2}$ & $\mathbf{1 0 0}$ & & \\
\hline
\end{tabular}

Dari siklus 2 ini menunjukkan adanya kenaikan jumlah ketuntasan siswa dan rata-rata hasil belajar yaitu ketuntasan 28 siswa (87,50\% dari 32 siswa) sedangkan yang mendapatkan nilai di bawah KKM yaitu 4 siswa (12,50\% dari 32 siswa). Siklus 2 ini menunjukkan adanya kenaikan jumlah ketuntasan siswa dan rata-rata hasil belajar dari siklus 1 yaitu ketuntasan siswa naik sebesar 6 siswa $(18,75 \%$ dari 32 siswa) dan kenaikan rata-rata sebesar 2,46. Secara terperinci, ketuntasan hasil belajar siklus 2 Subtema 3 Peristiwa Mengisi Kemerdekaan dapat dilihat pada diagarm lingkaran di bawah ini. Berdasarkan grafik lingkaran siklus 2 di atas, nampak pada setelah dilakukan tindakan jumlah siswa yang tuntas ada 28 siswa $(87,50 \%)$ sudah melebihi harapan peneliti untuk persentase ketuntasan minimal $85 \%$ dari jumlah keseluruhan kelas. Pencapaian hasil belajar berdasarkan hasil pengukuran yang dilakukan dengan tes dan nontes terhadap hasil belajar siswa dalam pembelajaran menggunakan pendekatan PBL pada siklus 1 dan siklus 2 terjadi peningkatan hasil belajar. Hasil belajar siswa pada penilitian ini mengalami peningkatan pada setiap siklusnya dapat dibandingkan berdasarkan ketuntasan belajar siswa kelas 5 SD pada prasiklus, siklus 1 dan siklus 2 dapat dilihat pada Gambar 3 dan 4.

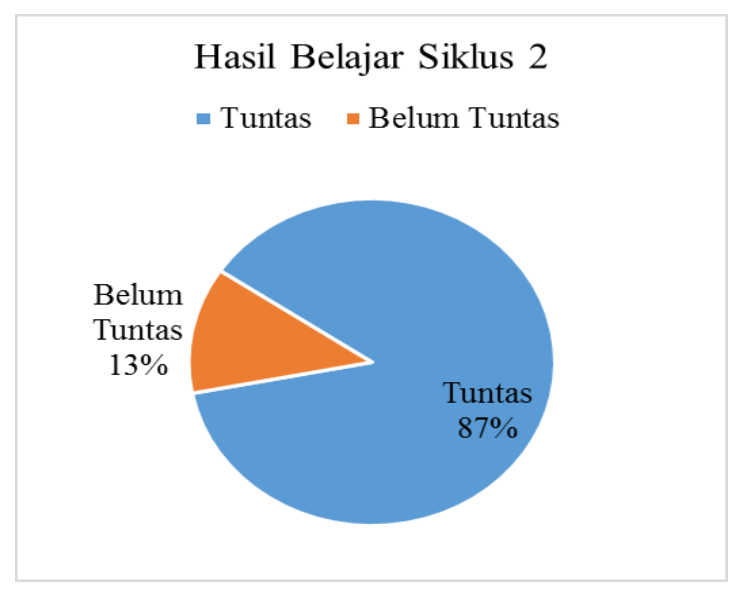

Gambar 3. Diagram Lingkaran Hasil Belajar Tematik Berdasarkan Ketuntasan Siklus 2

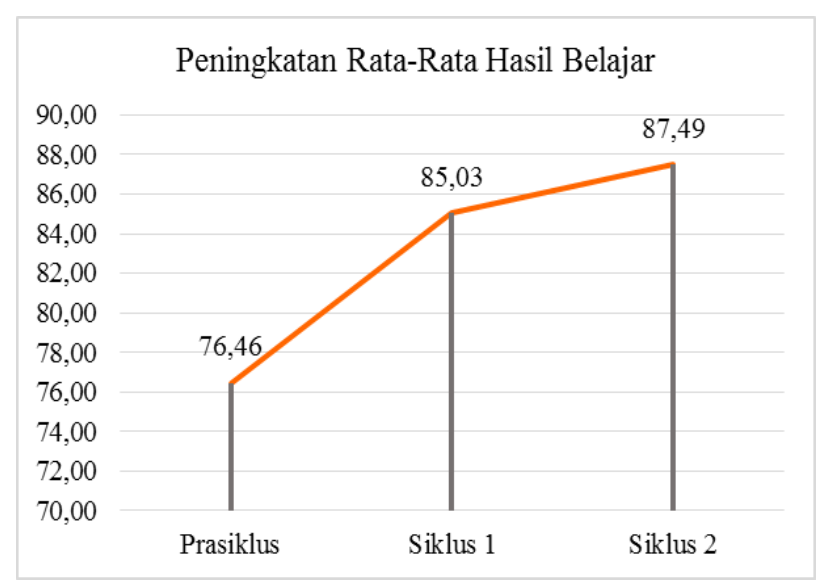

Gambar 4. Grafik Peningkatan Rata-rata Hasil Belajar Tematik

Berdasarkan Gambar $4 \mathrm{di}$ atas dapat dijabarkan peningkatan hasil belajar berdasarkan ketuntasan dari prasiklus 76,46 meningkat menjadi 85,03 pada siklus 1 kemudian meningkatkan lagi menjadi 87,49 pada siklus 2. Dari hasil belajar tematik maka dapat disimpulkan bahwa pembelajaran melalui pendekatan PBL dapat meningkatkan hasil belajar siswa. Setelah didapatkan hasil pada tiap siklus, analisis penelitian dilanjutkan dengan uji prasyarat data hasil belajar tematik kelas 5 SD yang telah berdistribusi normal dan homogen, uji analisis berikutnya adalah uji statistik inferensial dengan uji beda atau t-test (Independent Sample T-Test). Hasil perhitungan perbandingan rerata prasiklus dan siklus 1 dapat dilihat pada Tabel 5.

Tabel 5. Distribusi Hasil Belajar Tematik Berdasarkan Rata-rata Prasiklus dan Siklus 1

\begin{tabular}{llrrrr}
\hline & \multicolumn{5}{c}{ Group Statistics } \\
\hline Siklus & N & Mean & Std. Deviation & \multicolumn{1}{c}{ Std. Error Mean } \\
Belajar & Pra Siklus & 32 & 76,46 & 10,647 & 1,882 \\
& Siklus 1 & 32 & 85,03 & 4,958 &, 876 \\
\hline
\end{tabular}




\begin{tabular}{|c|c|c|c|c|}
\hline \multicolumn{5}{|c|}{ Independent Samples Test } \\
\hline \multicolumn{2}{|c|}{ Levene's Test for Equality of Variances } & \multicolumn{3}{|c|}{ t-test for Equality of Means } \\
\hline $\mathrm{F}$ & Sig. & $\mathbf{t}$ & df & Sig. (2-tailed) \\
\hline 37,973 & 0,000 & $-\frac{-5,328}{-2000}$ & 62 &, 000 \\
\hline & & $-5,328$ & 43,841 & 000 \\
\hline
\end{tabular}

Kondisi prasiklus pada penelitian ini adalah kondisi kelas yang belum diberi tindakan atau kebiasaan pembelajaran secara konvensional oleh guru menunjukkan hasil rata-rata 76,46. Kemudian diberikan tindakan pada siklus 1 menunjukkan rata-rata 85,03. Dengan memberikan tindakan pada siklus 1 ini berarti menunjukkan perbedaan yang dilihat dari hasil rata-rata pada prasiklus dengan siklus 1 . Perbedaan rata-rata kelas hasil belajar ini menunjukkan peningkatan sebesar 8,57. Dengan melihat nilai rata-rata prasiklus dengan siklus 1 , maka hasil dari uji t adalah $-5,328$ yang berarti rata-rata hasil belajar prasiklus lebih rendah daripada rata-rata hasil belajar siklus 1 . Dengan df 62, maka nilai signifikansi 0,000 tidak lebih besar dari 0,05 maka terdapat perbedaan yang signifikan atau perbedaan yang bermakna. Sehingga dengan tindakan PBL meningkatkan hasil belajar pada siklus 1. Untuk melihat bahwa perbedaan ini bukan kebetulan, maka diberikan tindakan kembali pada siklus 2. Setelah diberikan tindakan pada siklus 2, maka diperoleh hasil perbedaan antara prasiklus dengan siklus 2 seperti pada Tabel 6.

Tabel 6. Distribusi Hasil Belajar Tematik Berdasarkan Rata-rata Prasiklus dengan Siklus 2

\begin{tabular}{|c|c|c|c|c|c|}
\hline & Siklus & $\mathbf{N}$ & Mean & Std. Deviation & Std. Error Mean \\
\hline Hasil & Pra Siklus & 32 & 76,46 & 10,647 & 1,882 \\
\hline Belajar & Siklus 2 & 32 & 87,49 & 4,958 & ,876 \\
\hline \multicolumn{6}{|c|}{ Independent Samples Test } \\
\hline \multicolumn{3}{|c|}{ Levene's Test for Equality of Variances } & \multicolumn{3}{|c|}{ t-test for Equality of Means } \\
\hline & & Sig. & $\mathbf{t}$ & df & Sig. (2-tailed) \\
\hline \multicolumn{2}{|c|}{37,973} & 0,000 & $\begin{array}{l}-5,328 \\
-5,328 \\
\end{array}$ & $\begin{array}{r}62 \\
43,841 \\
\end{array}$ & $\begin{array}{l}0,000 \\
0,000 \\
\end{array}$ \\
\hline
\end{tabular}

Tindakan kegiatan pembelajaran prasiklus dengan siklus 2 menunjukkan adanya perbedaan yang terlihat pada skor rata-rata hasil belajar yang diperoleh. Rata-rata hasil belajar yang diperoleh pada siklus 2 yaitu 87,49 ini menunjukkan adanya peningkatan dari prasiklus ke siklus 2 sebesar 11,03 lebih besar daripada selisih antara rata-rata hasil belajar prasiklus dengan siklus 1 . Dengan melihat nilai rata-rata prasiklus dengan siklus 2, maka hasil dari uji t adalah 5,328 yang berarti data rata-rata hasil belajar prasiklus lebih rendah daripada rata-rata hasil belajar siklus 2. Dengan df 62, maka nilai signifikansi 0,000 tidak lebih besar dari 0,05 maka terdapat perbedaan yang signifikan atau perbedaan yang bermakna. Sehingga dengan tindakan PBL meningkatkan hasil belajar pada siklus 2.

Tabel 7. Distribusi Hasil Belajar Tematik Berdasarkan Rata-rata Siklus 1 dan Siklus 2

\begin{tabular}{llllrr}
\hline & \multicolumn{1}{c}{ Siklus } & N & Mean & \multicolumn{1}{c}{ Std. Deviation } & Std. Error Mean \\
\hline Hasil & Siklus 1 & 32 & 85,03 & 7,567 & 1,338 \\
Belajar & Siklus 2 & 32 & 87,49 & 5,015 &, 887 \\
\hline
\end{tabular}

\begin{tabular}{|c|c|c|c|c|}
\hline \multicolumn{5}{|c|}{ Independent Samples Test } \\
\hline Levene's Test for Equ & Variances & t-tes & ality of Mc & \\
\hline $\mathbf{F}$ & Sig. & $\mathbf{t}$ & df & Sig. (2-tailed) \\
\hline 2,977 & 089 & $\begin{array}{l}-1,519 \\
-1,519\end{array}$ & $\begin{array}{r}62 \\
53,830 \\
\end{array}$ & $\begin{array}{l}0,134 \\
0,135\end{array}$ \\
\hline
\end{tabular}

Berdasarkan hasil uji t siklus 1 dan siklus 2 tidak adanya signifikansi karena nilai signifikansi $0,089>0,05$ tetapi dilihat dari nilai t sebesar $-1,519$ yang berarti bahwa rata-rata nilai siklus 2 lebih tinggi daripada rata-rata nilai siklus 1 yang artinya pembelajaran dari siklus 1 mengalami peningkatan saat pembelajaran siklus 2 meskipun kenaikan rata-rata sedikit.

\section{Pembahasan}

Hasil analisis penelitian menunjukkan bahwa pembelajaran tematik terpadu dengan pendekatan PBL dapat meningkatkan hasil belajar tematik dan berpengaruh terhadap meningkatkan keterampilan 
siswa, hal ini dibuktikan dengan perolehan persentase ketuntasan pada siklus I sebesar 68,75\% serta dilanjutkan siklus II meningkat menjadi 87,50\%. Temuan yang diperoleh pada penelitian ini sejalan dengan temuan hasil penelitian yang dilakukan oleh (Enjoni \& Febriyanto, 2020; Pamungkas et al., 2018; Puspita et al., 2018; Syafriana, 2017) yang juga menunjukkan bahwa kelebihan dari pendekatan PBL yakni mampu meningkatkan hasil belajar siswa dengan peningkatan rata-rata persentase hasil belajar siswa pada ketuntasan siklus 1 yaitu 66\% dengan nilai rata-rata 72 dan pada siklus 2 hasil belajar yang mencapai ketuntasan mencapai 94\% dengan nilai rata-rata 93.

Hasil yang diperoleh dalam penelitian ini tidak terlepas dari penggunan pendekatan PBL dalam proses pembelajaran, hal ini dikarenakan pendekatan PBL mampu mengajak siswa untuk saling berdiskusi dan berpikir kritis dalam menganalisis permasalahan yang diberikan oleh guru sehingga pembelajaran ini memotivasi siswa untuk saling bekerjasama dalam menemukan pemecahan masalah yang tepat (Prasetyo, 2018; Purwaningsih, 2019). Pelaksanaan pembelajaran dengan menggunakan pendekatan PBL dilakukan melalui beberapa kegiatan pembelajaran seperti membentuk kelompok, menyimak pokok permasalahan, mengklarifikasi masalah, mendefinisikan masalah, menganalisis masalah, mengajukan pertanyaan, merumuskan hipotesa, menetapkan langkah-langkah penyelesaian masalah, mengumpulkan informasi yang sesuai atau melakukan eksperimen, menganalisis informasi yang telah didapatkan, membuat laporan, menyajikan karya laporan pemecahan masalah, dan menganalisis dan mengevaluasi proses mengatasi masalah menjadikan siswa lebih aktif dalam proses pembelajaran (Dewi et al., 2019; Herfina et al., 2020; Kenedi, 2019). Dimana proses pembelajaran yang seperti ini akan cenderung berpusat kepada siswa, dan memaksimalkan peran siswa dalam kegiatan belajar.

Proses pembelajaran yang berpusat kepada siswa atau biasa disebut dengan student centered merupakan tujuan utama dari pelaksanaan pembelajaran tematik. Pembelajaran tematik menuntut siswa untuk mampu memahami berbagai bidang ilmu pengetahuan dalam satu proses pembelajaran dan mengaitkannya dengan lingkungan sekitar (Setiawan, 2020). Secara sederhana pembelajaran tematik diartikan sebagai model pembelajaran yang mengintegrasikan atau menggabungkan beberapa muatan pelajaran dalam satu proses pembelajaran yang memungkinkan siswa secara individu maupun kelompok aktif secara fisik dalam menggali dan menentukan konsep serta prinsip-prinsip keilmuan secara bermakna dan autentik (Rusman, 2017; Sari et al., 2018). Dalam pembelajaran tematik guru berperan sebagai fasilitator yang bertugas untuk membimbing dan menuntun siswa dalam melaksanakan proses pembelajaran (Yanthi et al., 2020). Pembelajaran tematik mampu memberikan pengalaman belajar yang baru, dimana siswa dapat memahami berbagai bidang ilmu dalam satu kali proses pembelajaran.

Kegiatan pembelajaran tematik dengan menggunakan pendekatan PBL dapat dilakukan dengan menyajikan pembelajaran secara berkelompok dan menyajikan satu permasalahan, sehingga siswa lebih antusias dalam mengikuti pembelajaran dan membangkitkan komunikasi siswa dengan siswa lainnya dan berproses secara ilmiah dalam memecahkan masalah yang sedang dihadapi. Selain itu, melalui pembelajaran tematik dengan menggunakan pendekatan PBL guru dapat memaksimalkan kegiatan tanya jawab yang kemudian dapat membantu siswa untuk memecahkan masalah dengan mudah, serta membuat siswa merasa terdorong untuk mempelajari materi yang diberikan oleh guru, karena siswa terlibat langsung pada proses pembelajaran dalam menemukan pemecahan masalah sehingga keaktifan siswa meningkat (Hamdayana, 2014).

\section{SIMPULAN}

Berdasarkan hasil penelitian dan pembahasan, maka dapat disimpulkan bahwa peningkatan hasil belajar tematik kelas 5C Tema 7 Peristiwa dalam Kehidupan, muatan pelajaran Bahasa Indonesia, IPS, dan IPA dapat diupayakan melalui pendekatan $P B L$ pada siswa kelas 5C SD semester 2 tahun pelajaran 2020/2021 terbukti. Peningkatan hasil belajar tematik kelas 5C dapat diupayakan melalui pendekatan PBL dengan langkah-langkah pembelajaran PBL yaitu membentuk kelompok, menyimak pokok permasalahan, mengklarifikasi masalah, mendefinisikan masalah, menganalisis masalah, mengajukan pertanyaan, merumuskan hipotesa, menetapkan langkah-langkah penyelesaian masalah, mengumpulkan informasi yang sesuai atau melakukan eksperimen, menganalisis informasi yang telah didapatkan, membuat laporan, menyajikan karya laporan pemecahan masalah, dan menganalisis dan mengevaluasi proses mengatasi masalah.

\section{DAFTAR RUJUKAN}

Ainin, M. (2017). Efektifitas Penggunaan Pendekatan Pembelajaran Berbasis Masalah ( Problem Based Learning ) Dalam Pembelajaran Matakuliah Metodologi Penelitian Bahasa Arab. Jurnal Bahasa, Sastra, Seni, Dan Pengajaran, 45(2), 197-207. https://doi.org/ 10.17977/um015v45i22017p197. 
Aji, W., Sulasmono, B. S., \& Setyaningtyas, E. W. (2019). Upaya Meningkatkan Hasil Belajar Dan Keterampilan Proses Siswa Melalui Model Pembelajaran Problem Based Learning Di Kelas IV SD N Tingkir Tengah 02. Jurnal Basicedu, 3(1), 47-52. https://doi.org/10.31004/basicedu.v3i1.70.

Ananda, R., \& Fadhilaturrahmi. (2018). Analisis Kemampuan Guru Sekolah Dasar Dalam Implementasi Pembelajaran Tematik Di SD. Jurnal Basicedu, 2(23), 11-21.

Chanifah, M., Relmasira, S. C., \& Hardini, A. T. A. (2019). Upaya Meningkatkan Kemampuan Berpikir Kritis Dan Hasil Belajar Pada Pembelajaran Matematika Menggunakan Model Pembelajaran Problem Based Learning Pada Siswa Kelas V SD. Jurnal Basicedu, 3(1), 163-168. https://doi.org/10.31004 /basicedu.v3i1.96.

Dewi, N. P. F., Koeswanti, H. D., \& Radia, E. H. (2019). Upaya Peningkatan Hasil Belajar Dan Keaktifan Pembelajaran Tema 8 Subtema 1 Menggunakan Model Problem Based Learning (PBL) Dengan Diperbantukan Media 3D Watercycle Pada Siswa Kelas V SD N Tumbrep 01. Jurnal Basicedu, 2(1), 299-305. https://doi.org/10.31004/basicedu.v3i2.6.

Eismawati, E., Koeswanti, H. D., \& Radia, E. H. (2019). Peningkatan hasil belajar matematika melalui model pembelajaran problem based learning ( PBL) siswa kelas 4 SD. Jurnal Mercumatika: Jurnal Penelitian Matematika Dan Pendidikan Matematika, 3(2), 71-78. https://doi.org/10.26486/ jm.v3i2.694.

Enjoni, E., \& Febriyanto, F. (2020). Peningkatan Hasil Belajar Siswa SD Menggunakan Model Problem Based Learning Berbasis Keterampilan Proses Sains Pada Mata Pelajaran IPA. Jurnal Cerdas Proklamator, 8(2), 64-76. https://doi.org/10.37301/jcp.v8i2.60.

Gultom, M., \& Adam, D. H. (2018). Pengaruh Pendekatan Pembelajaran Problem Based Learning Terhadap Kemempuan Berpikir Kritis Di MTs Negeri Rantauprapat. Jurnal Pembelajaran Dan Biologi, 4(2), 1-5. https://doi.org/https://doi.org/10.36987/jpbn.v4i2.1595.

Hamdayana, J. (2014). Model dan Metode Pembelajaran Kreatif dan Berkarakter. Ghalia Indonesia.

Herfina, H., B, A., \& Kaimudin, L. O. (2020). Penerapan Model Problem Based Learning Untuk Meningkatkan Hasil Belajar Siswa Pada Tema Peristiwa Dalam Kehidupan Di Kelas V SDN 17 Kendari. Jurnal Ilmiah Pembelajaran Sekolah Dasar, 2(2), 10. https://doi.org/10.36709/jipsd. v2i2.13881.

Kenedi, A. K. (2019). Peningkatan Hasil Belajar Siswa Pada Pembelajaran Ipa Dengan Menerapkan Strategi Problem Based Learning (PBL) Di Sekolah Dasar. Jurnal Ilmiah Pendidikan Guru SD, 1(1). https://doi.org/10.31326/jipgsd.v1i1.285.

Muhith, A. (2018). Problematika Pembelajaran Tematik Terpadu di Min III Bondowoso. Indonesian Journal of Islamic Teaching, 1(1), 45-61. http://jurnalpasca.iain-jember.ac.id/ejournal/index.php/IJIT /article/view/23.

Pamungkas, A. D., Kristin, F., \& Anugraheni, I. (2018). Meningkatkan Keaktifan Dan Hasil Belajar Siswa Melalui Model Pembelajaran Problem Based Learning (PBL) Pada Siswa Kelas 4 SD. NATURALISTIC: Jurnal Kajian Penelitian Pendidikan Dan Pembelajaran, 3(1), 287-293. https: //doi.org/10.35568 /naturalistic.v3i1.268.

Prasetyo, I. B. (2018). Peningkatan Proses Dan Hasil Belajar Muatan Ipa Tema 8 Subtema 1 Dengan Menggunakan Pendekatan Saintifik Model Problem Based Learning (PBL) Pada Siswa Kelas 4 SD. Journal for Lesson and Learning Studies, 1(3). https://doi.org/10.23887/jlls.v1i3.15028.

Purnaningsih, W., Relmasira, S. C., \& Asri Hardini, A. T. (2019). Upaya Peningkatan Kemampuan Berpikir Kritis Dan Hasil Belajar Tematik Melalui Model Problem Based Learning (PBL) Kelas V SD. Naturalistic: Jurnal Kajian Penelitian Pendidikan Dan Pembelajaran, 3(2), 367-375. https: //doi.org/10.35568/naturalistic.v3i2.406.

Purwaningsih, S. (2019). UPAYA Meningkatkan Hasil Belajar Siswa Dengan Mengunakan Metode Problem Based Learning Dalam Pembelajaran IPS Di Kelas V SDN 36 Cakranegara. Media Bina Ilmiah, 14(4), 2443. https://doi.org/10.33758/mbi.v14i4.355.

Puspita, M., Slameto, S., \& Setyaningtyas, E. W. (2018). Peningkatkan Hasil Belajar Matematika Siswa Kelas 4 Sd Melalui Model Pembelajaran Problem Based Learning. Justek: Jurnal Sains Dan Teknologi, 1(1), 120. https://doi.org/10.31764/justek.v1i1.416.

Rusman. (2017). Model-Model Pembelajaran Mengembangkan Profesionalisme Guru. Rajawali Pres.

Sari, N. A., Akbar, S., \& Yuniastuti. (2018). Penerapan Pembelajaran Tematik Terpadu di Sekolah Dasar. Jurnal Pendidikan: Teori, Penelitian, Dan Pengembangan, 3(12), 1572-1582. https://doi.org/ 10.17977/jptpp.v3i12.11796.

Setiawan, A. R. (2020). Pembelajaran Tematik Berorientasi Literasi Saintifik. Jurnal Basicedu, 4(1), 51-69.

Setiowati, R. (2019). Upaya Meningkatkan Hasil Belajar Ipa Materi Daur Air Melalui Model Pembelajaran Problem Based Learning. Dinamika Jurnal Ilmiah Pendidikan Dasar, 10(1). https://doi.org/ 10.30595/dinamika.v10i1.3879. 
Silaban, R., Panggabean, F. T. M., Hutapea, F. M., Hutahaean, E., \& Alexander, I. J. (2020). Implementasi problem based-learning (pbl) dan pendekatan ilmiah menggunakan media kartu untuk meningkatkan hasil belajar peserta didik tentang mengajar ikatan kimia. Jurnal Ilmu Pendidikan Indonesia, 8(2), 69-76. http:/ / ejournal.uncen.ac.id/index.php/JIPI.

Syafriana, D. (2017). Penerapan Model Problem Based Learning (PBL) Dalam Pendekatan Saintifik Untuk Meningkatkan Hasil Belajar IPA Kelas V SDN 63 Surabayo. Jurnal Inovasi Pendidikan Dan Pembelajaran Sekolah Dasar, 1(1). https://doi.org/10.24036/02017117932-0-00.

Titik, S., Ika, H., \& Wulandari, S. (2017). Implementasi Gerakan Literasi Sekolah pada Pembelajaran Tematik di Sekolah Dasar. Jurnal Sekolah Dasar: Kajian Teori Dan Praktik Pendidikan, 26(2), 116123. https://doi.org/https://doi.org/10.17977/um009v26i22017p116.

Triwibowo, R., Badarudin, B., \& Heru Muslim, A. (2020). Peningkatan Keterampilan Berpikir Kritis Dan Sikap Kemandirian Belajar Menggunakan Model Problem Based Learning Pada Tema 7 Di Kelas V MIM 01 Sambong. Pendas: Jurnal Ilmiah Pendidikan Dasar, 5(1). https://doi.org/10.23969/jp.v5i1.2922.

Wahyuni, H. T., Setyosari, P., \& Kuswandi, D. (2016). Implementasi Pembelajaran Tematik Kelas 1 SD. Jurnal Edcomtech, 1(2), 129-136. http://journal2.um.ac.id/index.php/edcomtech/article/view/ 1799.

Wardani, N. S. (2012). Asesmen Pembelajaran SD. Widya Sari Press.

Yanthi, Marhaeni, \& Dantes. (2020). Analisis Tentang Cerita Anak Yang Bermuatan Sikap Dan Muatan Pembelajaran Terkait Dengan Tema Kayanya Negeriku Kurikulum 2013 Kelas IV Sekolah Dasar Berbasis Etnopedagogik. Jurnal Penelitian Dan Evaluasi Pendidikan Indonesia, 10(2), 112-122. https://doi.org/https://doi.org/10.23887/jpepi.v10i2.3524. 